\title{
ADDRESSING MULTI-STAKEHOLDER CONFLICTS IN THE COASTAL ZONE THROUGH A SPECIAL AREA MANAGEMENT (SAM) PROCESS: A CASE STUDY IN REKAWA OF THE SOUTHERN SRI-LANKA
}

\author{
NA Pethiyagoda ${ }^{1 *}$ and $\mathrm{O}$ Amarasinghe ${ }^{2}$ \\ ${ }^{1}$ Department of Animal Science, ${ }^{2}$ Department of Agricultural Economics and Extension, Faculty of Agricul- \\ ture, University of Ruhuna, Mapalana, Kamburupitiya, Sri Lanka
}

Accepted: $28^{\text {th }}$ June 2011

\begin{abstract}
It is accepted globally that management of the coastal zone should be done through an integrated process. Special Area Management (SAM) is a particular form of Integrated Coastal Zone Management (ICZM), which addresses multi-stakeholder conflicts in environmentally sensitive areas. The most important characteristic of the SAM process is that it is community based and collaborative. Yet, a proper mechanism to deal with such conflicts had to be instituted for SAM to be successful. A study was carried out to examine the relevance of SAM in Rekawa, an environmentally very sensitive coastal area in Southern Sri Lanka. A number of stakeholders, such as marine fishers, lagoon fishers, hoteliers, farmers, turtle conservationists, coral miners, etc. were identified, who generated negative externalities on each other giving rise to conflicts. By using Participatory Rural Appraisal (PRA) techniques, the issues confronted by each stakeholder group were studied along with their perceptions and suggestions for resolving such conflicts. The study attempted at finding how far SAM was able to cope with the conflicts and effectively manage the coastal zone at Rekawa. Stakeholders had placed a high reliance on SAM, but proposed the establishment of a Coordinating Committee consisting of all stakeholders, as the most appropriate tool to create a common flat form to bring all stake holders together to form a common coastal zone plan. Yet, the study found a number of prerequisites, for successful operation of SAM, including the provision of appropriate legal and official status to the proposed Coordinating Committee.
\end{abstract}

Key words: Integrated Coastal Zone Management, Special Area Management, Stakeholders

\section{INTRODUCTION}

Coastal Zone Management is becoming increasing urgent due to rapid exploitation and development of coastal areas and it is widely accepted to handle through an integrated process (Torella and Salamanca 2002). Special Area Management (SAM) is a particular form of Integrated Coastal Zone Management (ICZM), which addresses multi-stakeholder conflicts in environmentally sensitive areas. It is a locally based, geographically specific planning process which involves the affected communities and provincial agencies in the process of coastal resource management, by building community level support through a highly participatory process, creating community based management groups. Participation of all stakeholders is voluntary (Coastal Zone Management Plan 1997).

*Corresponding author: niyomipethiyagoda@yahoo.com
Rekawa of southern Sri Lanka is one of the environmentally sensitive areas, where SAM was implemented. It is a rural area where people depend strongly on the natural systems for their livelihood. Four main types of occupation provide employment for the working population of the Rekawa area, which include marine fishing, lagoon fishing, and agriculture tourism. Each of these occupational groups or stake holder groups tried to maximize its welfare by a particular type of behavior, which was guided by its own laws. This created negative externalities on other groups, giving rise to conflicts. SAM attempted at dealing with these conflicts and effectively managed the natural resources in the area (Special area Management Plan 1997). However, the Tsunami of 2004 , led to the collapse of SAM and today people urgently feel the need for the re-establishment of SAM. 
This study is an attempt as preliminary study at understanding the diverse conflicts confronted by stakeholders in the area and their suggestions for the re-establishment of SAM.

\section{METHODOLOGY}

The study area was Rekawa Lagoon which is the dominant feature of the Rekawa Special Area Management site. Most of the people are engaging in lagoon fishing, marine fishing, and agriculture which are concerned as main stake holders. From each stake holder group, people were selected purposively who live adjoining area of the lagoon, with the assistance of Grama Niladari, fishery's inspectors and leaders of the cooperatives. Participatory Rural Appraisal (PRA) techniques were employed to elicit information from above stakeholder groups. Twenty individuals were selected from each stakeholder group and each such group was invited to Participatory Rural Appraisal sessions to elicit information on externalities generated by diverse stake holders causing conflicts and, also their suggestions in resolving such conflicts. Finally, a workshop was organized with the participations of representatives of above stakeholder groups, all relevant state and nonstate officials operating in the area. The stakeholder groups presented their cases at the workshop and possible mitigatory measures, mitigatory mechanisms, were discussed at group discussions which followed. In addition, articles, books etc. used to obtain secondary information related to study.

\section{RESULTS AND DISCUSSION}

\section{Causes for the failure of Special Area Man- agement Process}

Absence of a proper legal status for SAM, excessive dependence on voluntary participation of government officials, weaknesses of divisional secretariat (the local administration), poor participation of government officials, lack of awareness of the SAM process among people, low extent of participation of some resource user groups and weaknesses of community based organizations, were all noted as factors causing the post-Tsunami collapse of the SAM process. The causes are identified by the Pair wise Ranking.
Identify the conflicts among the stakeholders in the Coastal Zone in Rekawa The impacts by stakeholders to each other were identified by free scoring. Results indicated that the major negative impacts on lagoon fishermen were the breaching of the sandbar by hoteliers and farmers without mutual understanding, water pollution due to agricultural runoff, garbage disposal by hoteliers, growing interest in shrimp culture and increased pollution of lagoon waters by dumping of garbage. The marine fishers were confronted with an array of problems due caused by closure of beach access roads, disposal of waste on the beach by hoteliers and some groups engaging in coral mining, which decreased the near shore fish catch. Impacts on farmers were identified as lack of mutual understanding between fishermen and farmers on the breaching of sand bar at lagoon mouth.

\section{Effective means of dealing with multi stake holder problem under Integrated Coastal Zone Management}

At the work shop, all the stake holders suggested the establishment of a 'Special Area Management Coordinating Committee' consisting of all resource user groups, representatives of state and non-state institutions and local and international non-governmental agencies. The stakeholders suggested more active participation of the community based organizations as principal stakeholders, in planning and implementation of development and management measures with local and central government agencies. In this way, it was expected that the local community would gain a sense of ownership of the planning process. Strengthening of community organizations and establishing new ones were also suggested, to enable the resource user groups to participate actively in the management of natural resources and livelihoods. Regular and active participation of government officials was emphasized and, the need to make them responsible for decisions taken by the co-coordinating body. Periodic monitoring of the activities of co-coordinating body was considered as a necessity.

Earlier, Rekawa Special Area Co-ordinating Committee (RSACC) provided the forum to develop and implement the SAM plan which met monthly to resolve conflicts among main resource users. But it was limited its capacity 
to resolve problems timely and effectively (Special Area Management Plan, 1997). Therefore, in the workshop, people of Rekawa have suggested a new structure called "subcommittee" to effective resolution of conflicts. The conflicts of resource users would present their issues to subcommittee before presenting main co-coordinating body. Therefore, this subcommittee is to gather before the main committee gathering. If problems are not resolved by the subcommittee, they are presented before main co-ordinating committee. Three representatives from each community based organizations are selected for subcommittee. But legal actions can't be taken by the community. Therefore, it was suggested that government officials should be included for subcommittee. Permanent members of community based organizations must include to this forum to continue this process.

In conclusion, the study highlighted the importance and faith, the diverse stakeholders of Rekawa had placed on SAM. The major strategy proposed was the establishment of a Coordinating Committee consisting of all stakeholders, as the most appropriate tool in taking SAM forward. New management institution as "Sub-committee" was suggested by people to resolve conflicts effectively and timely.

It is great opportunity to create a common flat form to bring all stake holders together to form a common Coastal Zone Plan. Yet, the study found a number of pre-requisites, for successful operation of SAM, including the provision of appropriate legal and official status to the proposed Coordinating Committee. Further importance of adapting to community participation in resource management was emphasized. Community based organizations were suggested to be strengthened and built new ones to enable them to participate actively in the management of their natural resources and livelihoods with the intention of giving a sense of ownership for the coastal zone planning process.

\section{ACKNOWLEDGMENT}

This study was supported by grants from UNDP ART GOLD program in connection with the student internal programme with Department of Agricultural Economics and Extension, Faculty of Agriculture, University of Ruhuna, Sri Lanka.

\section{REFERENCES}

Coastal Zone Management Plan. (1997). Coastal Conservation Department, Colombo,Sri Lanka.

Special Area Management Plan for Rekawa lagoon. (1997). Coastal Conservation Department, Sri Lanka.

Special Area Management Plan for Kalametiya lagoon (2005). Coastal Conservation Department, Colombo, Sri Lanka.

Torella, M; M, Salamanca, A ; 2002 ; Institutional issues and perspectives in the management of fisheries and coastal resources in South East Asia, Malaysia, Sun Printers Sdn Bhd. 